\title{
Diyaliz Hastalarında Sosyal Bütünleşme İhtiyacı
}

\section{Öğrt. Grv. Yasemin Oğuz Güner ${ }^{1^{*}}$}

Geliş tarihi: 11.09.2019

Kabul tarihi: 22.10.2019

\section{Atıf bilgisi:}

IBAD Sosyal Bilimler Dergisi

Sayı: 5 Sayfa: $175-184$

Yıl: 2019 Dönem: Güz

This article was checked by intihal.net. Similarity Index 23\%

1 Akdeniz Üniversitesi, Türkiye, yaseminoguzguner2016@gmail.com, ORCID ID 0000-0003-1508-2988

* Sorumlu yazar

\begin{abstract}
ÖZ
Kronik böbrek yetmezliği, hemodiyaliz, periton diyalizi ya da böbrek nakliyle tedavisi yapılan hastalıklardan biridir. Diyaliz tedavisi, hastanın sağ kalımını sağlasa da, yaşam kalitesi hala üzerinde çalışılması gereken sorunların başında gelmektedir. Yaşam kalitesi kavramının içinde, fiziksel sağlık, ruh sağlığı, bağımsızlık düzeyi, sosyal ilişkiler, yaşama ve sağlığa bakış açısı, beklentiler ve alışkanlıklar yer almaktadır. Kronik hastalıklarda birey yașam boyu az ya da çok hastalık etkilerini yaşar. Bu gruptaki bireylerde, hastalığa bağlı günlük yaşam aktiviteleri ve iyilik hali bozulması, yaşam kalitesinin düşmesine neden olur. Bu bağlamda yaşam kalitesini arttırmak için sadece medikal gelişmelerin yeterli gelmediği, hastaların psikososyal desteğe de ihtiyaç duydukları bilinmektedir. Psikososyal destek, bazı hastalıklar için uygulansa da çoğunlukla diğer kronik hastalıklarda göz ardı edilmekte, medikal başarıya odaklanılmaktadır. Psikososyal destek için ülkemizde multidisipliner ekibin içinde ihtiyaç duyulan meslek grupları henüz yer almamaktadır. Yaşam kalitesinin hastalıkla ilişkili olarak azaldığı diyaliz hastalarında, sosyal bütünleşme ihiyacını ortaya koymak amaciyla yapılan bu çalışmada; sosyal etkileșimde bozulmayla başlayan yalnızlık, anksiyete ve depresyon, tedaviye uyum güçlüğü ve intihara eğilim gibi önemli sorunlara neden olduğu görülmüştür. Bir hastalık toplumda ne kadar çok kişiyi ilgilendiriyorsa o kadar önemli olup halk sağlığı sorunu olarak ele alınmalıdır. Kronik hastalıklar bu yönden incelendiğinde morbidite ve mortalitesi önemli olan hastalıklar olduğu görülür. Bu bağlamda böbreğin korunmasından böbrek yetmezliğine, tedavi koşullarına kadar medikal desteğin dışında, hastalık sosyal bütünleşmedeki engelleri yönünden de çözüm üretilmesini beklemektedir. Çalışmada son dönem böbrek yetmezliği olan hastalarda yaşam kalitesini bozan başlıca sorunlar; İş ve eğitim engeli, sağlık giderleri, psikolojik sorunlar, aile içi rol ve statü kaybı ile sosyal çevre sorunları altında toplanıp, alan yazın taraması ile irdelenmiştir.
\end{abstract}

Anahtar Kelimeler: Diyaliz Tedavisi, Sosyal Bütünleşme, Yaşam Kalitesi, Psikososyal Destek. 


\title{
Needs of Social Integration in Dialysis Patients
}

\section{Lec. Yasemin Oğuz Güner ${ }^{\text {* }}$}

First received: 11.09 .2019

Accepted: 22.10.2019

\section{Citation:}

IBAD Journal of Social Sciences

Issue: 5 Pages: 175-184

Year: $2019 \quad$ Session: Fall

This article was checked by intihal.net. Similarity Index 23\%

1 Akdeniz Üniversitesi, Türkiye, yaseminoguzguner2016@gmail.com, ORCID ID 0000-0003-1508-2988

* Corresponding Author

\begin{abstract}
Chronic renal failure is one of the diseases treated by hemodialysis, peritoneal dialysis or renal transplantation. Although dialysis treatment provides the survival of the patient, quality of life is still one of the main problems to be studied. The concept of quality of life includes physical health, mental health, level of independence, social relations, perspective on life and health, expectations and habits. In chronic diseases, the individual experiences the effects of more or less disease throughout his / her life. In this group of individuals, activities related to daily living and impaired well-being caused by the disease cause poor quality of life. In this context, it is known that not only medical developments are sufficient for improving the quality of life, but also patients need psychosocial support. Although psychosocial support is applied for some diseases, it is mostly ignored in other chronic diseases and focused on medical success. There are no occupational groups needed in the multidisciplinary team in our country for psychosocial support. In this study conducted to reveal the need for social integration in dialysis patients whose quality of life decreased in relation to the disease; Loneliness, anxiety and depression, difficulty in adherence to treatment and suicidal tendency have started. The more important a disease is in the society, the more important it should be and it should be considered as a public health problem. When chronic diseases are examined in this respect, it is seen that they have important morbidity and mortality. In this context, apart from medical support, from kidney protection to kidney failure and treatment conditions, the disease also expects to find solutions in terms of barriers to social integration. In this study, the main problems that impair quality of life in patients with end-stage renal disease; Work and education barriers, health expenses, psychological problems, loss of family role and status and social environment problems were gathered under the field literature review.
\end{abstract}

Keywords: Dialysis Treatment, Social Integration, Quality of Life, Psychosocial Support. 


\section{GíRIŞ}

Toplumları oluşturan bireyler arasında dezavantajlı gruplar ve daha çok yoksullarla ilgili ortaya çıkan sosyal dışlanma konusu dikkat çekmektedir. Ne yazık ki, toplumsal düzenin bireysel görevlerinden biri olması gereken sosyal sorumluluklar, artık proje oluşturmadan ya da yasal zorunluluklar olmadan yaptırımı güçlükle sağlanmaktadır. Sosyal bütünleşmenin sağlanamadığı durumlarda sosyal dışlanma yani; bireyin toplumla bütünleşmesini sağlayan sivil, politik, ekonomik ve sosyal haklara bazı kişi ve grupların ulaşamaması durumları oluşmaktadır (Walker ve Walker, 1997, s. 8). Bu bağlamda işsizlik ile maddi sorunlar ve eğitimsizlikle birlikte sosyal güvence sorunları, daha da büyüyen ekonomik sorunlar ve sosyal sorunlar başta olmak üzere, bireysel ve toplumsal düzeyde katlanarak artan, sorunlar yumağı haline dönmektedir. Sosyal dışlanmanın yoksulluğa, yoksulluğun da sosyal dışlanmaya neden olduğunu belirten çalışmalar da güncelliğini korumaktadır (Şahin, 2010, s. 71-79). Dolayısıyla sosyal dışlanma yaşayan grupların belirlenip tekrar topluma katılımını sağlamak için toplumun genelini ilgilendiren sorunların çözümlenmesiyle mümkün olabilecek dinamik bir süreçtir.

\section{DIYYALİ TEDAVISİ ALAN HASTALARDA SOSYAL YAŞAM}

\subsection{Sosyal Dışlanma Kavramı}

Sosyal dışlanma, sosyal kaynaklı yetersizlikler kadar ekonomik, kültürel ve politik yetersizliklerle de meydana gelmektedir. Sosyal dışlanma kavramının merkezinde, yoksullukla bağlantısı olduğu tespit edilen çalışmalarda, topluma katılmayla ilgili kişisel ve psikolojik sorunlar, sosyal ilişkiler, sosyal destek ihtiyacı gibi maddi olmayan etkenlerin de söz konusu olduğu gösterilmektedir (Short, 1999).

Dışlanma kavramı, "yoksulluk", "altsınıf", "eşitsizlik", "yabancılaşma”, "bütünleşememe” gibi terimlerle birlikte kullanılmaktadır. Bilhassa dezavantajlı gruplarda, bunlardan biri ya da birkaçı nedeniyle sosyal bütünleşememe sorunu yaşanmaktadır. Yoksullukta temel sorun maddi kaynaklar, sistemsel sorunların sonuçları, ekonomik hak kayıpları iken sosyal dışlanmada toplumla bütünleşme, sistemsel süreçler, vatandaşlık hakları ile ilgilidir. Ölçülebilirlik açısından karşıllaştırıldığında ise yoksulluk ölçülebilirken, sosyal dışlanma ölçülememekte diğer bir değişle somutlaştırılamamaktadır (Kenyon, Lyons ve Rafferty, 2002, s. 208 ). Kronik hastalık tek başına yada sosyokültürel yetersizlik ve yoksullukla birlikte derinleşerek giden sosyal dışlanmaya neden olmaktadır. Farrington, sosyal dışlanmayı süreçler, fertler ve çevresel etmenler ş̧eklinde üç grupta incelemektedir. Buna göre birinci kategoride dışlanma, birbiriyle bağlantılı ve çok yönlü durum ve süreçlerden ibarettir (Atılgan ve Çakar, 2007, s. 68-69). İkinci kategori ise bireylerin, gruplarla ve dolayısıyla toplumla bütünleşmede yaşadıkları dışlanma sorunlarıdır (Bhalla ve Lapeyre, 1997). Üçüncü kategori ise dışlanmanın çevresel faktörlerinden aile ve sosyal çevre başta olmak üzere istihdam, sosyal devletle ilgili sorunlar gelmektedir. Bu üç kategoriden biri ya da birkaçındaki sorunlar sosyal dışlanmaya neden olmaktadır. Birinde olan bozulma diğerini etkilemekte ve sorunlar zincirleme olarak diğer sistemleri etkilemektedir (Alden ve Thomas, 1998, s.1-6).

\subsection{Sosyal Dışlanma ve Hastalık İlişskisi}

Akut hastalıklar ile kronik hastalıklar arasındaki farklılıklardan önemli bir tanesi hastalığın süresi konusudur. Akut hastalıklar başlar ve bir süre sonra biter ve sonuçta hastalık, iyileşme veya ölümle sonlanır. Diğer bir deyişle, bu sürenin sonunda hastalık gündemden çıkar. Oysa kronik hastalıklar kısa zamanda bitmez, yıllar boyu sürer. İnsanlar bu hastalıklarla, toplum da bu hastalarla birlikte yaşamak durumundadır. Schouten ve arkadaşlarının diyaliz hastalarında yaşam kalitesi, depresyon, hospitalizasyon ve mortalite gibi çok değişkenli regresyon modeli üzerinde yaptıkları çalışmalarında, hastalığın oluşturduğu medikal ve sosyal nedenlerin mortalite üzerindeki etkisi anlamlı bulunmuştur (Schouten ve ark, 2019). Diyaliz hastalarında, Beck Depresyon Envanteri-II (BDI), bozulan yaşam kalitesi ile depresyon arasında ilişkinin ortaya konduğu çalışmalarda, yapılabilecekler için tedaviye ilave destek ihtiyacını gündeme taşımaktadır. Yaşam kalitesinin diyaliz hastalarında bozulma sebepleri; damar giriş yolları, diyaliz merkezi ve hastaneye bağll1ık, komplikasyonlar, yorgunluk, anksiyete gibi medikal sorunlar, yetişkin hastanın iş bulması ve işe devam etmesinde, öğrencinin eğitimini sürdürmesindeki zorluklar, psikososyal sorunlar, mortalite riski, diyet kısıtlılığı, hareket kısıtlılığı, aile birlikteliğinin sürdürülmesindeki maddi ve manevi zorluklar, organ nakli bekleme süreci, rejeksiyon nedeniyle tekrar 
diyalize geri dönüş gibi etkenler başı çekmektedir. Stresin yoğun yaşandığı hasta ve aileleri kendi içlerinde bütünlüğü korumada zorlandıkları gibi sosyal çevreyle de yaşadıkları uyumsuzluklar nedeniyle dezavantajlı grup olarak kabul edilebilmektedirler.

Kronik böbrek yetmezliği, glomerül filtrasyon hızının normalin \%75'i azaldığında, sebep olan hasar ortadan kaldırılsa da renal fonksiyonlardaki bozulma geri döndürülemez. Üremik sendrom, ciddi renal yetmezliğin klinik belitisi olup azotlu madde ve diğer yıkım ürünlerinin toksik etkileri sonucu ortaya çıkan belirti ve bulgulardan oluşur. Üremik sendrom genel olarak kreatinin klirensi 10ml/dak/1.73 $\mathrm{m}^{2}$ 'nin altına düştüğü zaman gelişir. Üremi bütün sistemleri etkiler. Mortalite açısından en önemlisi kardiyovasküler sistem üzerindeki etkileridir. İştahsızlık, bulantı, kusma, nefeste amonyak kokusu, gastrit, enterit, peptik ülser gibi gastrointestinal komplikasyonlar hastaların bazen ilk şikayetleri olabilir. $\mathrm{Su}$ ve tuz retansiyonuna bağlı olarak son dönem böbrek yetmezlikli hastaların yaklaşı \% \% hipertansiyon görülür (Daugirdas ve ark, 2003). Çoğunlukla hasarlı böbreklerden eritropoeitin üretiminde azalmaya, daha az olarak dolaşımdaki eritropoez inhibitörlerine ve kısalmış eritrosit ömrüne bağlı olarak anemi gelişir. Yanı sıra üreminin yol açtı̆̆ başlıca nörolojik bulgu ve şikayetler baş ağrısı, uyku bozuklukları, kas krampları, tremor, konvülziyonlar, stupor, koma, huzursuz bacak sendromu, periferik nöropati, otonomik nöropatiye bağlı ortostatik hipotansiyon ve impotans olarak sıralanabilinir. Son dönem böbrek yetmezliği olan hastaların beyinlerinde çeşitli bölgelerde guanidosüksinik asit, metil guanidin ve kreatinin düzeyleri normalden yüksek tespit edilmiştir. Üremik ansefalopati ile ilişkili olarak asidoz, hiponatremi, hiperkalemi, hipokalsemi, hipermagnezemi, sıvı yüklenmesi ve dehidratasyonun yanı sıra paratiroit hormonu başta olmak üzere çeşitli hormonların serum seviyelerinin artmışıı. Diyaliz tedavisi alan hastalarda diyaliz demansıve disequlibrium sendromu görülebilir. Disequlibrium sendromunda patogenez tartışmalı olmakla birlikte diyaliz ile plazma solüt düzeyinin hızlı bir şekilde düşürülmesiyle plazma, beyin dokusundan daha hipotonik hale gelir ve su plazmadan beyin dokusuna geçerek bu sendroma yol açar. Diyaliz demansı, subakut başlangıçlı, progresif ve genellikle fatal seyirli bir durumdur. Sivı-elektrolit dengesizliği dişında üremik hastalarda karbonhidrat intoleransı, hiperürisemi, hipertrigliseridemi, protein malnütrisyonu, büyüme-gelişme bozukluğu, infertilite, seksüel disfonksiyon, amenore gibi endokrin ve metabolik bozukluklar da görülür (Selamet, 2005). Bu bağlamda dünyada Renal Replasman Tedavilerindeki yaşam kalitesinin hem genel popülasyon, hem de başka kronik hastalıkları olanlara göre daha düşük olduğu bulunmuştur (Garcia ve ark, 2010). Diyaliz tedavisi alan hastalarda bu nedenle tedavinin tek amacı yaşam süresini uzatmak değil yaşam kalitesini arttıracak psikososyal sorunlara da eğilmek olmalıdır. Bu tedavi süreci ile birlikte sosyal bütünleşmeyi engelleyen başlıca sorunları ve sonuçlarını şu alt başlıklarda toplamak mümkün;

\section{1- İş ve eğitim engeli}

Çalışan hastalarda iş devamlılığının tedavi, kontroller, komplikasyonlar nedeniyle hastaneye yatış gibi etkenlerden sekteye uğraması, ister kamu ister özel sektörde iş gücü ve verimliliğin düşüklüğü sonucu işlerini bırakma ya da işlerine son verilmesi şeklinde sonuçlanmaktadır. Diyaliz seanslarının gün içinde 5 kere yapıldığı Periton diyalizi, ya da haftada 3 gün 4'er saat yapıldığı Hemodiyaliz, aylık takipler için doktor ziyaretleri ve komplikasyonlarda bir hafta süren hastane yatışı gibi nedenlerle devlet kurumu yada özel iş yerinde çalışmak mümkün olamamaktadır. Aynı nedenler öğrenim hayatını da sekteye uğratmaktadır. Kronik hastalığın belirtilmesi ile yeni bir iş bulamama, okula devam zorunluluğunu yerine getirememe ve akademik başarıda düşüklük gibi sonuçlara neden olmaktadır. Yaşam kalitesi ile eğitim durumu arasındaki ilişki incelendiği çalışmada, eğitim durumlarına göre fonksiyonel durum ve genel sağlık anlayışı alanlarında istatistiksel olarak anlamlı bir fark bulunmuştur. Aynı çalışmada Yaşam kalitesi ile meslek arasındaki ilişki incelendiğinde, esenlik ile meslek arasında istatistiksel olarak anlamlı fark tespit edilmiştir (Küçük, 2008).

Bu durum toplumsal, sosyal, aile içinde görev kayması, maddi sorunlar başta olmak üzere pek çok etkenle somatik, ruhsal, bilişsel faktörler ile yaşam kalitesi düşmektedir.

\section{2- Sağlık giderleri}

Sağlık giderleri, sosyal güvencenin hastaya büyük destek sağladığı diyaliz tedavisi, devletin önemli sağlık harcama kalemlerinden biridir. Bu sebeple Türkiye ve dünyada katlanarak artması ön görülen kronik hastalıklar için tedbir almak üzere halkın bilgilendirilmesi çalışmaları yapılmaktadır. Aylık Kt/V 
(Diyaliz Yeterliliği), üre, ürik asit, potasyum, kalsiyum, lökosit, paratiroit hormonu, fosfor, demir, hemotokrit oranı, D vitamin ve albumin gibi değerlerin yanı sira solunum, enfeksiyon ve kardiyovasküler takipler, radyolojik sonuçlar gibi rutin kontrollerin yapılması gereklidir. Kronik diyaliz tedavisi için bir sağlık merkezine bağlı kalarak hemodiyaliz için sağlık sigortası desteği yeterli olamamaktadır. Pek çok beraberinde ihtiyaç duyulan başta beslenme ve diğer sağlık giderleri için bütçeye ihtiyaç duyulmaktadır. İşsizlik sorunu, ailedeki birey sayısı, yetersiz beslenme, enfeksiyona yakalanma oranını, hastanede yatış süresini daha da arttırarak daha fazla sağlık giderine neden olmaktadır. ABD Renal Veri Sistemi 2018 verilerine göre dünyada 2 milyon kişinin SDBY (Son Dönem Böbrek Yetmezliği) ve böbrek hastalığı tanısı almış olup bu sayının yılda \% 5-7 oranında artmaya devam ettiği belirtilmektedir. Sağlık Bakanlığı 2018 verilerine gore toplam 63.349 Sağlık Bakanlığı, özel ve üniversitede, toplam 882 merkezde diyaliz tedavisi almaktadır (Faaliyet raporu, 2018: 98). Hemodiyaliz bakımı, Medicare sistemine ABD'de yıllık olarak hasta başına ortalama 90.000 dolar, toplam 28 milyar dolara mal olmaktadır. Değişen sağlık ekonomisi öncelikleri, 1945'lerde tedaviye erişim iken, 1970'lerde kalite, 1990'larda ise maliyet olduğu gösterilmektedir. Bir Kanada raporunda y1llık maliyetlere bakıldığında "Periton Diyalizi (PD) ve Hemodiyaliz (HD) yöntemleri için; Sürekli Ayaktan Periton Diyalizi (CAPD):20029, Devamlı Devirli Periton Diyalizi (CCPD):24937, merkezde HD:30626, Ev HD:17547 Kanada Doları" şeklinde belirtilmiştir. Türkiyede HD için hasta başına yılda 21,385 Dolar, PD için ise 20,765 Dolar Maliye Bakanlığı Bütçe Mali Kontrol Genel Müdürlüğü verileri Kamu, Yeşilkart, SGK harcamaları için 2008 y1lında sağlık giderlerinin \%5'ini oluşturduğunu belirtmişken, 2018 yılı politika ve tedbirlerde tıbbi cihazların kalitesi, kullanımı ve bunlara yönelik harcamaların etkinliğin kontrolü ile başlayan kısıtlılıklar halen devam etmektedir.

\section{3- Psikolojik sorunlar}

Haftada üç gün dört saat ile tedavi sonrasındaki iş gücünde düşüklük nedeniyle hem de komplikasyonlar, kronik damar giriş yolunun enfeksiyöz ve nonenfeksiyöz sorunları, hareket kısıtll1ı̆̆ı, beden imajında değişim, hastaneye bağımlı yaşam biçimi, diyet kısıtlılığı, çocuk hastalarda gelişim gerilikleri gibi yaşam kalitesini düşüren sorunlar hem de anksiyete ve depresyona bağlı psikolojik sorunlar yaşanmaktadır. Aile içerisinde görev kaybı, sosyal ilişkilerde bozulmalar, cinsel sorunlar, ilaçların yan etkilerine bağlı olumsuzluklar özellikle altta yatan psişik yatkınlıkların daha da alevlenmesine neden olmaktadır.

Hastalarda anksiyete, hüzün, suçluluk duygusu, sosyal dışlanma, çalışamama ve okuyamama ile yetersizlik ve yalnızlık duygusu, değersizlik duygusu, intihara eğilim, tedaviyi reddetme ya da tedaviye uyumsuzluk gösterme şeklinde görülmektedir. Kronik böbrek yetmezliği hastalarının ortalama yaşam ömürleri 15-20 yıl arasındadır. Dolayısıyla kronik hastalığa bağlı yaşam süresi uzasa da yaşam kalitesinin niteliği önemli bir sorundur. Ancak multidisipliner tedavi içerisinde uzman psikolog ve psikososyal destek yetersizliğinin çözümlenmesine ihtiyaç bulunmaktadır. Psişik sorunlar hastanın yaşam kalitesini daha da bozarak tedaviye uyumunu, ilaç kullanımı ve diyaliz seanslarına devamlılı̆̆ını, diyete uyumsuzluğunu daha da arttırmaktadır. Bu da sosyal sermayenin bozulması ve sosyal bütünleşme zorluklarına zemin hazırlamaktadır.

\section{4- Aile İçi Rol ve Statü Kaybı}

Hemodiyaliz ya da Periton diyalizi, vücutta işlevini yerine getiremeyen böbreğin süzme işlemi gerçekleşse de pek çok dengedeki bozukluklar sistemlerdeki bozukluklarla devam eder. Diğer yandan organ nakli seçeneği olmayan hastalar için diyaliz hayat kurtarıcı bir yöntemdir. Hastalarda gastrointestinal, dermatolojik, metabolik, endokrin, hematolojik gibi devam eden sorunlar, hastanın fiziksel işlev kaybı, rol ve statü kaybı, özerklik kaybına neden olur. Çalışamama neticesinde ekonomik yetersizlik ve sosyal kayıplar ile artan ajitasyon, sinirlilik, kaygı bozukluğu oluşur. Konsantrasyon bozukluğu, libido azalması, dermansızlık, iştah değişikliği gibi durumlar, hastanın uyumsuz hissettiği, kendi aile ortamıyla çatışmalara neden olur. Erkeklerde aile içinde hem baba hem eş olarak etkinliği düşmekte ve bakım gerektiren bir hasta olarak görev değişikliğine neden olmaktadır. Benzer durum kadınlar için de söz konusu olmakla birlikte bakımı yapacak olan erkek olduğunda durum daha zorlaşarak aile birlikteliğinin bozulduğu gözlenmektedir. Böbrek yetmezliğinde çocuğu olan ailelerde, sağlıklı çocukların ihmali söz konusu olabilmektedir. Diyaliz hastalarının eşleri üzerinde yapılan araştırmalar, eşlerin hastaya psikolojik yakınlık gereksinimi yanı sıra agresyon içinde olduklarını göstermiştir. Diyaliz hastasının parçalanmış ailesi ile fonksiyonel durum arasında istatistiksel olarak 
anlamlı fark bulunmuştur. Diyalizin başlangıç dönemlerinde aile bireylerinin hasta ile aşırı ilgili oldukları, sonra ilgilerini kaybettikleri, dost ve akrabaların da arayıp sormadıkları gözlenmektedir (Cimili, 2003, s. 88-92). Çalışma ve eğitime devam edememe sonucunda hem ekonomik, hem eğitim hem de sosyal bütünleşme bozulmaktadır.

\section{5- Sosyal Çevre Sorunları}

Kronik Hastalıkların, yetişkinlerde olduğu gibi çocuk hastalarda, çocuğun bedensel ve ruhsal gelişimine olumsuz etkileri sonucu, yaşıtlarıyla ilişki sorunları, özgüven ve kişilik gelişimindeki engeller, aşırı aile ilgisi ve korumacı yaklaşım nedeniyle çocuğun sosyalleşmesini olumsuz etkiler. Kronik hastalığa sahip bireylerde hastalığa yaklaşım ve mücadele durumlarıyla ilgili olan denetim odaklarının ölçüldüğü bir çalışmada, özellikle çocuk hastaların daha dıştan denetimli oldukları ve bunda çocuğun yaşı, annebabanın öğrenim düzeyinin etkili olduğunu gösterir (Gültekin ve Baran, 2005). Ayrıca kronik hastalığı olan çocuklarda hastalığın tanısı, çocuğun daha önce hastanede yatma süresi ve hastalığını bilme durumu denetim odağı puanlarında farklılığa neden olmaktadır. Yetişkin hastalarda ve çocuk hastaların ebeveynlerinde tükenmişlik sendromu, hastalığı red etme ve tedaviye uyumsuzluk her iki yaş grubunun denetim odaklarındaki sorunlardan kaynaklanmaktadır. Olumsuz beden algısı, depresyon, davranış bozukluğu, uzun sure okuldan uzak kalma ile akademik başarıda düşüklük, başarısızlık duygusu ile sosyal bütünleşmede güçlük yaşanmasına neden olmaktadır. Tedavi sürecinin belirsizliği, ölüm korkusu, yaşam beklentisi konularında ise yetişkin hasta ve çocuk hastanın kaygılı ebeveynlerinde en sık karşılaşılan yaklaşım sorunlarıdır. Kronik diyaliz tedavisi yapılan hasta zamanının büyük bir çoğunluğunu hastalıkla ilgili olarak hastane ortamında geçirmektedir. Bu durumda iş yada okul çevresi, komşuluk hatta akrabalık ilşkilerinde giderek uzaklaşmalar oluşmaktadır. Artık hastanın sosyal çevresi diğer hastalar, onların aileleri ve sağlık personellerinden oluşmaktadır. Sosyokültürel ve sosyoekonomik sorunlarının daha da belirgin ve içinden çıkılamaz hal almaktadır. Hastalığın aile ortamından başlayarak toplumsal etkileri söz konusudur. Bu durumda psikososyal destek, stresle baş etme becerilerinin geliştirilmesi, pozitif ayrımcılık ile iş ve eğitim fırsatlarının sağlanması gerekmektedir.

\section{DIYYALIZZ HASTALARINDA SOSYAL DESTEK İHTIYYACI}

Sosyal destek, ruhsal ve fiziksel sağlık üzerinde duyuşsal, bilişsel ve davranışsal etkiye sahiptir (Cohen $\&$ ark, 2000). Sosyal destek, hastalığın ortaya çıkmasını engellemekte ve hasta bireylerde pozitif yöndeki sağlık davranışlarını geliştirerek, iyileşmeyi hızlandırmaktadır (Lindström, 2008). Stresle baş etmek için fiziki ve ruhsal sağlığı koruma ve tedavisinde, bireyin önce yakın çevresi sonra da toplumun desteği gerekmektedir. Stresli yaşam koşulları, sağlık sorunlarıyla birleşince hastalık ile sosyal destek arasındaki ilinti konusu dikkat çekmektedir. Baş etmede kişisel ve toplumsal yetersizliklerin, kötü alışkanlıklara eğilimi, yalnızlık, dışlanma ve intiharı tetiklediği bilinmektedir (Gibson, 2010). Sosyal desteği yüksek olan kişilerde algılanan sağlık düzeyi de daha yüksek seviyede olmaktadır (Dutta, 2008). Diğer yandan sosyal sermayesi zayıf kişilerde intiharlara daha çok rastlanmaktadır (Frumkin ve ark, 2004).

Hemodiyaliz sırasında ve seanslar arasında hastalarda yaşam kalitesini bozan en sık görülen komplikasyonlar; hipotansiyon (diyalizlerin \%20-30'unda), kramplar (\%5-20), bulant1 ve kusma (\%515), baş ağrıs1 (\%5), göğüs ağrıs1 (\%2-5), sirt ağrisı (\%2-5), kaşıntı $(\% 5)$, titreme ve ateş $(<\% 1)$ (Bergman \& ark, 2003). Kronik hastalığa sahip kişiler sağlıklılara oranla, daha az sayıda kişi ya da arkadaşla ilişki kurmaktadırlar (Halpern, 2005). Bu nedenle sosyal sermayenin zayıf olmasının bir taraftan kişileri hasta olmaya iterken, diğer taraftan hasta olmanın da sosyal sermayeyi azalttığını söylemek yanlış olmayacaktır. Sosyal sermayenin sağlık üzerindeki etkilerini ortaya koymaya çalışan birçok çalışmanın sonucuna göre sosyal yalıtım birtakım hastalıkların ortaya çıkmasına neden olmaktadır. Günümüzde özellikle yalnız yaşayan, arkadaşı olmayan ya da sosyal ilişkileri zayıf olan kişilerde alzheimer ve demans hastalığı riski bulunmaktadır.

\section{SOSYAL BÜTÜNLEŞME}

Sosyal bütünleşme kavramını, Augusic Comte tarafindan "sosyal uyuşma (Con-sensus Social)" ifadesinden sonra Amerikalı ve İngiliz sosyal bilimciler "kültürel bütünleşme" olarak kullanıldığı görülür. Sosyal bütünleşme, XIX. yüzyıl sosyolojisinde önemli bir yer tutmuş olan bütünleşmenin ana konusu, toplumdaki çeşitli unsurların bir arada ve birbirini destekleyerek çalışması ile ilgili olmuştur. Bir toplumdaki tüm grupların ve sosyal yapısının tüm unsurları ile maddî ve manevî kültür unsurlarının bir 
araya gelerek, işleyen bir bütün meydana getirecek şekilde birbirlerini tamamlamalarına ve birbirleriyle kaynaşmalarına "sosyal bütünleşme" adı verilmiştir (Ozankaya, 1986). Maslow'un "ihtiyaçlar hiyerarşisi"ne göre, insanlar için maddi ihtiyaçlardan sonra ikinci sırada yer alan "güvenlik ihtiyacı"dır. Maslow'dan iki bin dört yüz yıl önce yaşamış olan Konfüçyüs de insan ihtiyaçları ve güven duygusu konusunda benzer bir sıralama yapmıştır. Konfüçyüs güven kavramına toplum ve devlet odaklı baktığı için iyi yöneticilerin görevlerini sayarken birinci sıraya halkın beslenmesini, ikinci sıraya fiziksel güvenliğin sağlanmasını ve buna ek olarak da bireylerin, halkın siyasal otoriteye, devlete olan güvenini koymuştur. Kısacası Konfüçyüs, sosyal ve siyasal düzenin karşılıklı olarak birey ve devlet bağlamında toplumsal güven duygusuna dayandığını vurgulamaktadır. Güven kaybolunca insan ilişkileri zedelenmekte ve toplumsal bütünleşmenin sağlanması güçleşmektedir. Bu psikososyal duygunun yokluğu hastalık ve ayrışmayı beslemektedir.

Sosyal ağlara katılım, sosyal bütünleşme olarak bilinmektedir (Günler, 2014). Evlilik, akrabalık, arkadaşlık, komşuluk, çeşitli sosyal ya da dini gruplara dahil olmak sosyal bütünleşmeyi arttırmaktadır. Sosyal ağlara katılım ve sosyal bütünleşmenin artışı, sosyal sermayenin de artışı anlamına gelmektedir. Sosyal iletişim ağları, sağlı ve hastalığı doğrudan ya da dolaylı olarak etkileyebilmektedir. Kişilerin sosyal ilişkileri ve toplumdan etkilenme düzeyleri sağlığa ilişkin davranışlarını etkileyerek, çeşitli hastalıklara maruz kalmalarına neden olabilmektedir (Cohen ve ark, 2000). Bu nedenle uzun yıllardan bu yana sosyal iletişim ağları sağlığın bileşenlerinden biri olarak kabul edilmektedir (Frumkin ve ark, 2004). Çeşitli ülkelerde yapılmış birçok çalışmanın sonucuna göre sağlık statüsü ile toplumsal iletişim arasında güçlü bir bağ bulunmaktadır (OECD, 2001). Genellikle düşük seviyede sosyal sermayeye sahip olanlar düşük düzeyde sağlık statüsüne ve sağlı̆̆ koruyucu davranışlara sahiptirler. Yine bu kişiler yüksek oranda sağlığa zararlı davranışlar, yüksek hastalanma ve ölüm oranlarına sahiptirler (Lopez, 2012). Karşılıklı güven ve toplumsal ağların yok olması insanların yalnız kalmalarına neden olmaktadır (OECD, 2001). Yalnızlık ise kişilerin psikolojik ve fiziksel hastalıklara maruz kalmalarını beraberinde getirmektedir.

Genel ve soyut bir kavram olarak "toplumsal güven", sosyal kurumlara olan güvenle ilgilidir. Kurumsal güven devlete olan güven ile devlete olan güven ise sosyal kurumlar aracılığıyla sağlanmaktadır. Toplumun güven duygusunun azalması ya da kaybolması ile ilgili olarak, kişilerin kurumlara olan güveni, sosyal araştırmalar yapılarak belirlenmektedir. Keza sosyal çözülme ve bozulma en somut biçimde kendini kurumlardaki çözülme ile göstermektedir (Yaka, 2018).

\subsection{Diyaliz Hastalarında Sosyal Bütünleşme}

Hastalıkların, kişisel ve toplumsal açıdan önemlerinin farklı olduğuna 1915 yılında Alman sosyal bilim adamı Alfred Grotjahn işaret etmiştir. Seyrek de olsa, kişinin kendi hastalığı kişisel açıdan önem taşırken, konuya toplumsal açıdan yaklaşıldığında, bir toplumda sık görülen, çok kişiyi öldüren ve çok kişiyi sakat bırakan hastalıklar önemli sağlık sorunu oluştururlar. Bir hastalık toplumda ne kadar çok kişiyi ilgilendiriyorsa o kadar önemli olup halk sağlığı sorunu olarak ele alınmalıdır. Kronik hastalıklar bu yönden incelendiğinde morbidite ve mortalitesi önemli olan hastalıklar olduğu görülür. Yetişkin yaş grubunda morbidite nedenleri hipertansiyon, kalp-damar hastalıkları gibi kronik ve dejeneratif hastalıklar ön sırada yer almaktadır.

Türkiye'de 2000 yılında yapılan hastalık yükü araştırmasının sonuçlarına göre 60 ve üzeri yaş grubunda erkeklerde ve kadınlarda en sık ölüm nedeni olan 10 hastalıktan 9 tanesinin kronik hastalıklar olduğu ortaya konmuştur. Aynı çalışmada kalp hastalıklarının 2030 yılında 400 binden fazla kişinin ölümüne yol açacağ 1 beklenmektedir. Benzer şekilde kanser ölümlerinin, gelecek 30 yıl içinde 2,5 kat, diyabet nedeniyle olan ölümlerin de 1,5 kat artacağı öngörülmektedir (TC Sağlık Bakanlığı Hıfzıssıhha Mektebi Müdürlüğü). $\mathrm{Bu}$ bağlamda, özellikle diyalize ihtiyacın böbrek yetmezliği sebepleri arasında kardiyovasküler hastalıklar, diyabet oranının artışı beraberinde böbrek yetmezliği insidansının da artışı demek olmaktadır.

Diyaliz tedavisinin başlatılmasıyla birlikte, yaşam kalitesindeki değişiklikler nedeniyle, ilk yıldan itibaren, değişen oranlarla psikiyatri desteği ihtiyacı söz konusudur. Bu hastalarda sık karşılaşılan psikiyatrik sorunlar depresyon, tıbbi tedaviye uyumsuzluk, cinsel fonksiyon bozukluğu ve rehabilitasyondaki zorluklardır (Akpolat ve Utaş, 1997). Sağlık hizmetlerinde ve teknolojideki gelişmelere paralel olarak insan ömrü uzamakta ve toplumlar giderek yaşlanmaktadır. Ancak, kronik ve 
dejeneratif hastalıkların ağılıkta olduğu sağlık sorunları, sosyal sorunlar ve yaşam kalitesi sorunları daha da fazla önem kazanmakta, üzerinde çalışma gerektirmektedir.

\section{SONUÇ}

Kronik böbrek hastalığı, dünyada ve ülkemizde epidemi halini almış önemli bir halk sağlığı sorunu olup başta Diyabet, Hipertansiyon gibi hastalıklara bağlı olarak gelişen, progresif ve irreversible böbrek harabiyetidir. Kronik hastalıklar tek başına tıbbi müdahelenin yetersiz kaldığı psikososyal desteğe ihtiyaç duyulan bu yönüyle hem sağlık hem sosyal alanın sorunudur. Hastalığın hayat boyu sürmesi nedeniyle hastanın diyaliz tedavisi, komplikasyonlar, takipler için zamanının büyük bir kısmı sık ve uzun süreli hastanede geçmektedir. Beraberinde ailenin de bakım, beslenme, diyaliz merkeziyle iç içe geçen, yaşam koşullarının hastalıkla yeniden şekillenmesi gerektiği bir süreçtir. Erkek hastalarda, çalışan hastalarda, okuyan hastalarda ise tedavi ve sosyal sorunların dışında ekonomik sıkıntılar ile aile bireyleri daha da etkilenmektedir. Çoğunlukla haftada üç gün dört saatlik tedavi süreci için ayrılacak süre çalışmayı da eğitim hayatını da olumsuz etkilemektedir. Kronik hastalıkla yaşam kalitesi arasında artan diyaliz ömrüne kıyasla istenen düzey elde edilemediği için hastalarda anksiyete, depresyon başta olmak üzere pek çok psikososyal sorunlar oluşmaktadır. Kronik hastalık tek başına ya da sosyokültürel yetersizlik ve yoksullukla birlikte derinleşerek giden sosyal dışlanmaya neden olmaktadır. Sosyal dışlanma, sosyal kaynaklı yetersizlikler, ekonomik, kültürel ve politik yetersizliklerle, topluma katılımda hastalıkla bağlantılı olan ya da olmayan kişisel ve psikolojik sorunlarla daha da artmaktadır. Sosyal dışlanma, diğer gruplardaki gibi kronik böbrek yetmezliği hastalarında da ölçülememekte ve somutlaştırılamamaktaysa da etkenler bireysel ve çevresel olarak toplumla bütünleşememede istihdam ve sosyal devletle ilgili sorunlar öne çıkmaktadır. Konfüçyus ve Maslow'un ihtiyaçlar ve güven konusunda sosyal ve siyasal düzenin karşılıklı olarak birey ve devlet bağlamında dezavantajlı gruplarda mevcut bütünleşme sorunların etkenlerini değerlendirilerek şekillendirilmesi gerektiği düşünülmektedir. Her geçen yıl artması ön görülen toplumdaki kronik hastalıklar ve böbrek yetmezliği birey sayısı konusunda tedbir ve çözümler üzerinde çalışılması gerekmektedir. Sosyal iletişim ağlarının sağlığın bileşenlerinden biri olduğu unutulmamalıdır.

Çalışmayla ilgili alanyazında özellikle farklı dezavantajlı gruplarda sosyal bütünleşme ile ilgili sorunların kronik hastalıklı olan hasta ve hasta yakınları üzerinde de var olduğu düşünülmektedir. Yapılan gözlemlerin nicel çalışmalarla desteklenmesi ve hem sağlık politikası üzerinde hem de konuda uzman mesleklerin devlet ve özel hastanelerde multidisipliner çalışma grubuna dahil edilmesi gerektiği düşünülmektedir. $\mathrm{Bu}$ bağlamda psikososyal desteğin yetersizliği kronik böbrek yetmezliğine sahip hastaların zorlu tedavi süreciyle düşen yaşam kalitesi sorunlarının oluşturduğu psikososyal sorunlar ve toplumla bütünleşememenin getirdiği ek stresörlerle daha da bozulmaktadır.

Bilgilendirme / Acknowledgement: $4^{\text {th }}$ International Scientific Research Congress (IBAD-2019), 25-26 Nisan 2019, Uppsala-SWEDEN, sözlü bildiri olarak sunulmuştur.

\section{KAYNAKÇA}

Alden, J. ve Thomas, H. (1998). Context and policy. International Planning Studies. Social Exclusion in Europe, 3(1), 7-14.

Bregman H, Daugirdas J. T ve Ing T. S (2003). Hemodiyaliz sırasında oluşan komplikasyonlar. Bozfakıoğlu S. (Çev.). Diyaliz El Kitabı içinde. (3. baskı), Ankara: Güneş Kitabevi.

Bhalla, A. ve Lapeyre , F. (1997). Towards an analytical and operational frame work, development and change. Social Exclusion, 28 (3), 1-6.

Bilir, N. (2006). Değişen sağlık örüntülerinde halk sağlığı çalışanlarının rolü. Kronik Hastalıklar ve Yaşlllık Sorunları Toplum Hekimliği Bülteni, (25), 3.

Blaxter, M. (1990). Health and lifestyle. London: Routledge.

Cimilli C. (2003). Hemodiyalizin psikiyatrik yönleri. Türk Nefroloji Diyaliz ve Transplantasyon Dergisi, 12(1), 88-92. 
Cohen, S. Gottlieb, B. H. ve Underwood, L. G. (2000). Social relation ship and health. Social Support Measurement and Intervention A Guide for Health and Social Scientists. New York: Oxford University Press.

Çakar, B.Y. ve Atılgan, G. (2007). Sunuş, yoksulluk ve sosyal dışlanma. Tes-İ̧̧ Dergisi, Haziran, 68-69.

Daugirdas, J.T, Blake, P.T. ve Ing, T.S.(2003). Diyaliz El Kitabı. Semra Bozfakıŏlu (Çev). Ankara: Güneş Kitabevi Ltd. Şti.

Dutta, M. J. (2008). Communicating health. Cambridge: Polity Press.

Eryiğit Günler, O. (2014). Sosyal sermaye, sağlık ve hastalık. KMÜ Sosyal ve Ekonomik Araştırmalar Dergisi, 16(26), 107-113.

Frumkin, H. Frank, L. ve Jackson, R. (2004), Urban sprawl and public health. Washington: Island Press.

Garcia T.W, Veiga J.P, Motta L.D, Moura F.J. ve Casulari LA.(2010). Depressed mood and poor quality of life in male patients with chronic renal failure under going hemodialysis. Rev Bras Psiquiat, 32, 369-374.

Gibson, A. (2010). Does social capital have a role to play in the health of communities. A Reader in Promoting Public Health. London: SAGE.

Gültekin, G. ve Baran, G. (2005). 9-14 Yaş grubu akut ve kronik hastalığı olan çocukların denetim odağı düzeylerinin incelenmesi. Türk Pediatri Arşivi, 40, 211- 220.

Halpern, D. (2005). Social capital. Cambridge: Polity Press.

Hançerlioğlu, O. (2001). Toplumbilim sözlüğü. İstanbul: Remzi Kitabevi.

Hyyppa, M. T. (2010). Health ties. New York: Springer.

Kenyon, S. Lyons ve G. Rafferty, J. (2002). Transport and social exclusion: Investigating the possibility of promoting inclusion through virtual mobility. Journal of Transport Geography, 10(3), 207219.

Küçük, M. (2008). Hemodiyaliz hastalarının yaşam kaliteleri, hasta özellikleri ve hemşirelik hizmetleri ile ilgili doyumları arasındaki ilişkinin incelenmesi. Yayımlanmamış yüksek lisans tezi. İç Hastalıkları Hemşireliği Anabilim Dalı. Afyon Kocatepe Üniversitesi, Afyon.

Lindström, M. (2008). Social capital and health-related behaviors. Social Capital and Health. New York: Springer.

Lopez, R. I. (2012). The built environment and public health. San Francisco: Jossey- Bass.

OECD (2001). The well- being of nations the role of human and social capital. Paris: OECD Centre for Educational.

Ozankaya, Ö. (1986). Toplumbilim terimleri sözlüğ̈̈. Ankara: Türk Dil Kurumu Yayınları.

Selamet, U. (2005). Üremik hastalarda görsel uyarılmış potansiyeller ve elektroretinogram değişiklikleri. Yayımlanmamış uzmanlık tezi.T.C. Haydarpaşa Numune Eğitim ve Araştırma Hastanesi 2. Dahiliye Kliniği, İstanbul.

Short, C. (1999). Poverty eradication and social integration. The Position of the UK. International Social Science Journal, Blackwell Publishers, Oxford, 51(162), 467-73.

Schouten, R.W, Harmse, V. J, Dekker, F. W ve Ballegooijen, W.V (2019). Dimensions of depressive symptoms and their association with mortality, hospitalization, and quality of life in dialysis patients: A cohort study. Psychosomatic medicine, 81(7), 649-658.

Şahin, M. M. ve Ünal, A. Z. (2010). Sosyal sermaye kuram uygulama eleştiri. İstanbul: Değişim Yayınevi.

Akpolat, T. ve Utaş, C. (1997). Hemodiyaliz hekimi el kitabı. (3.Baskı). Antalya: Türk Nefroloji Derneği.

T.C. Başbakanlık Devlet İstatistik Enstitüsü (2003). Ölüm istatistikleri.Ankara: DİE Matbaası. 
T.C. Sağlık Bakanlığı Hıfzıssıhha Mektebi Müdürlüğü (2005). Başkent Üniversitesi Ulusal Hastalık Yükü ve Maliyet Etkinlik Araştırması. Hastalık Yükü Final Raporu, Ankara.

T.C. Sağlık Bakanlı̆̆ı Faaliyet Raporu (2018). 22 Eylül 2019 tarihinde https://sgb.saglik.gov.tr/Dkmanlar/TC\%20Sa\%C4\%9Fl\%C4\%B1k\%20Bakanl\%C4\%B1\%C4\% 9F\%C4\%B1\%20Faaliyet\%20Raporu\%202018.pdf .adresinden erişildi.

Walker, A. \& Walker, C. (1997). Britain divided: The growth of social exclusion in the 1980s and 1990s, child poverty. London: Action Group.

Yaka, A. (2018). Sosyoloji yazıları, çatışma kültüründen uzlaşma kültürüne. İstanbul: Gündoğan Yayınları. 